\title{
GAINS AND LOSSES OF INDIA-CHINA TRADE COOPERATION - A GRAVITY MODEL IMPACT ANALYSIS
}

\author{
SWAPAN K. BHATTACHARYA \\ BISWA N. BHATTACHARYAY \\ CESIFO WORKING PAPER NO. 1970 \\ CATEgORY 7: TRAdE POLICY \\ APRIL 2007 \\ An electronic version of the paper may be downloaded \\ - from the SSRN website: \\ www.SSRN.com \\ - from the RePEc website: \\ www.RePEc.org \\ - from the CESifo website: www.CESifo-group.de
}




\title{
GAINS AND LOSSES OF INDIA-CHINA TRADE COOPERATION - A GRAVITY MODEL IMPACT ANALYSIS
}

\begin{abstract}
As revealed by the trade intensity indices, India and the People's Republic of China have significant bilateral trade potential, which remains unexplored until now. These countries are presently negotiating for free trade arrangements among them based on their complementarities. This paper makes an attempt to estimate the likely benefits in terms of gains or losses in imports of both India and China due to different preferential trading arrangements and free trade arrangements using the gravity model. Empirical results show that in the short run India's potential gain is relatively less compared to China because of its high tariffs but in the long run, India's gains are higher than China once its tariff levels are brought at par with them. Free trade arrangement is a win-win situation for both countries and is consistent with their growing dominance in the international trade.
\end{abstract}

JEL Code: F02, F04, F13, F14, F15.

Keywords: PTAs, FTA, gravity model, trade intensity indices, India- People Republic of China, bilateral trade flows, trade creation and trade diversion.

Swapan K. Bhattacharya National Graduate Institute for Policy Studies Japan - Tokyo
Biswa N. Bhattacharyay Principal Reform Coordination Specialist Office of the President Asian Development Bank Philippines - Manila bbhattacharyay@adb.org

The views expressed in this paper are the views of the authors and do not reflect the views or policies of the organizations to which the authors belong. The usual disclaimer will apply. 


\title{
Gains and losses of India-China Trade Cooperation - a Gravity Model Impact Analysis ${ }^{4}$
}

\author{
Swapan K. Bhattacharya ${ }^{5}$ and Biswa N. Bhattacharyay ${ }^{6}$
}

\section{Introduction}

Following the global trend, Asia also witnessed a shift in regional trade strategy from multilateral to subregional and bilateral trade agreements. Bilateral trade accords are on the ascendant, marking a shift from a regional emphasis on multilateralism. There are aggressive pursuit of these deals among Asian countries and between Asian and non-Asian countries. Subregional and bilateral regional cooperation and integration can help maximize the benefits of globalization, while minimizing its risks. But on a broader scale, the impetus for more regional integration in Asia has resulted from relatively slow progress in multilateral trade talks at the global level, and the benefits of free trade agreements (FTAs) in Europe and the Americas. In view of rapid activities in other regions, the opportunity costs of not accelerating subregional and bilateral regional integration are high for Asian countries (Bhattacharyay, 2006).

China and India have strong historical and cultural links and share many similarities. They possess centuries-old civilizations and unique histories. After pursuing inward-oriented policies in the early years of their development, China (since 1978) and India (since 1991) have increasingly deepened their economic integration and with the rest of the world. India is a late starter in the process of liberalization and opening up its economy, but it has been catching up well especially after 1991. India has been lagged behind China in almost all macro economic parameters including trade. This is evident from the fact that when China's total trade was $\$ 1155$ billion in 2004; India's figure was hovering around $\$ 173$ billion in the same period. Including trade in services India's figure stood at $\$ 254$ billion against China's figure of $\$ 1288$ billion in 2004. India's trade in merchandise goods increased to $\$ 239$ billion in 2005 . It is evident from the volume of trade of both countries, at least in the near future, India is not at all competitor to China but obviously China is the fierce competitor of India in the world market. This is because China has started liberalizing its economy much before India, as a result of which China's FDI flow is ten times higher than that of India.

China is much ahead of India in the degree of openness because of its incredible record of economic liberalization initiated since 1978, long before India's foray into economy reforms initiated in 1991. Degree of openness of China, which is measured by trade/GDP ratio, was $59.8 \%$ compared to $25 \%$ of India in 2004 . Surprisingly, trade/GDP ratio of USA was only $20 \%$ in 2004. China's share in the world trade was a miniscule $1.5 \%$ in 1950 , increased to $4.8 \%$ in 2002 and $6.81 \%$ in 2005 whereas India's share has been dropped from $2.2 \%$ in 1950 to $0.8 \%$ in 2002 and rose to $1.14 \%$ in 2005 . In spite of all odds, India-China bilateral trade has been

\footnotetext{
4 An earlier version of the paper was presented at the international conference on The Dragon and the Elephant: China and India's Economic Reforms held in Shanghai, PRC, on 1-2 July 2006. The views expressed in this paper are the views of the authors and do not necessarily reflect the views or policies of the organizations to which the authors belong. The usual disclaimer will apply.

5 Swapan K. Bhattacharya is Visiting Scholar, National Graduate Institute for Policy Studies, Tokyo.

6 Biswa N. Bhattacharyay is Principal Reform Coordination Specialist, Office of the President, Asian Development Bank, Manila.
} 
growing at a faster rate, which stood at $\$ 18$ billion in 2005 with the target of achieving $\$ 50$ billion in the next five years.

Twelve-fold increase in India-China trade in the last decade shows that India and China are competitors in many respects but also complementary and supplementary to each other. Substantial complementarities characterize the economic structures of China and India. While China has emerged as the manufacturing hub of the world, India's strengths in knowledgebased services and manufacturing are gaining recognition. The complementary strengths of the two economies can be exploited for mutual benefit. Opportunities for fruitful cooperation exist in many areas such as manufacturing, services, and investment. Their geographical proximity and large-sized economies would facilitate exploitation of these synergies (Bhattacharyay and De, 2005)

In order to enhance bilateral trade and promote economic cooperation, both China and India have started negotiations for a FTA. Though the Indian Government has been vigorously trying to conclude increasing number of bilateral/regional trading arrangements with different countries in last several years, however, it has expressed its reservation to conclude similar bilateral free trade agreement with China at this moment because of its higher nominal tariffs on its imports compared to other countries in one hand and existence of hidden subsidies in China on the other. In 2004, China's simple mean tariff was $9.8 \%$ and weighted tariff was $6.0 \%$, whereas the corresponding figures for India was $28.3 \%$ and $28.0 \%$ respectively during the same period. Apart from that India's bound tariff is still very high. It is $100 \%$ for primary goods, $150 \%$ for processed goods and $300 \%$ for edible oil. Though in its successive budget proposals, India has reduced its custom tariffs significantly. Presently peak tariff is $12.5 \%$, nearer to the ASEAN level of $12 \%$. Despite this, average collection rate of India is among the highest in the world.

Indo-China relationship has changed significantly in recent years because of its economic imperatives. Growing economic interactions are evident from the fact that in 2004-05, China became the third largest importer of Indian goods next to USA and UAE. USA's share in India's exports was $16.74 \%$, which was $8.96 \%$ for UAE and $5.79 \%$ for China in $2004-05$ from just oblivion state in 2000-2001. In imports, the performance is even much spectacular. From the state of almost non-entity a few years back, China has made incredible progress in its market penetration to India surpassing all its past predictions. China now emerges as the largest exporter to Indian market surpassing traditional alley of USA and UK. In 2004-05, China's share in India's total imports was $6.30 \%$ i.e. highest of all trading partners, followed by USA, whose share was $5.88 \%$.

Trade cooperation and integration between China and India can foster outward-oriented development and generate economic and social benefits, which could also be a countervailing measure to withstand the excesses of economic globalization. The objective of the paper is to examine the likely impact of a FTA between China and India. In this paper, gains and losses of both countries of concluding PTAs followed by FTA in their total trade as well as major commodities at the 2-digit HS categories will be examined. Gains and losses are measured in terms of increase in India's imports from China and vice-versa due to several PTAs with differential tariff rate reductions and if duties are withdrawn completely by both the countries through FTA.

This paper is divided into five sections. Section II deals with the trading pattern of India and China over the years. Section III shows the trade intensity indices of India and China in 19952005 and trade potentials between India and China as estimated by different researchers. In 
section IV, the likely impact of PTAs and FTA on bilateral trade between these two counties under different comparative-static scenarios are shown. Section $V$ analyses the results of the study, which shows under different hypothetical tariff-reduction scenarios, the extent of gains and losses of both countries. In section $\mathrm{VI}$, concluding observations are made.

\section{India's Trade with China: Trends and Patterns}

Indo-China trade has been growing very rapidly since mid-1990s. In 1994-95, India's export to China was $\$ 254.3$ million, which grew to $\$ 5344.88$ million in 2004-05 registering an exponential growth of $35.60 \%$ per annum. The trend of India's imports from China has shown a similar trend. India's import from China was $\$ 761.04$ million in $1994-95$, increased to $\$ 6768.92$ million in 2004-05, showing an annual exponential growth of $24.10 \%$. Total trade between India and China touched $\$ 18$ billion in 2005 . Total trade between two countries has been growing at an annual exponential rate of $28.13 \%$ between $1994-95$ and $2004-05$, which is much higher than the rate of growth of India's overall trade during this period. Even India's exports to China have been growing much faster rate than its total trade, which roughly grew by $20 \%$ annually in dollar terms in the same period.

India's exports to China were $\$ 5344.88$ million in $2004-05$, registering an impressive growth of $80.39 \%$ compared to $2003-04$, when it registered growth of $49.60 \%$ over previous year. This shows that India's exports to China have been growing very rapidly and significantly but not to the same extent China exports to India. In the same period, growth of India's overall export was only $26.15 \%$ and the share of China in India's total export was $6.64 \%$.

India's imports from China have also been increasing significantly over last ten years. India's import from China was $\$ 6768.92$ million in $2004-05$ showing a growth of $67 \%$ over the previous year. Another significant trend is that trade deficit has also been increasing over the years, which stood at $\$ 1424.04$ million in 2004-05 compared to $\$ 1101.04$ million of the previous year. Trade deficit was $\$ 506.74$ million in $1994-95$, which has been increasing continuously. If the growth rate of India's exports to China is maintained at the present level, it is expected that this gap will be narrowed down in the near future. As regards to India's total trade (both exports and imports) to China, it was $\$ 12113.8$ million in $2004-05$, registering a growth of $72.85 \%$ over the previous year. China's share to India's total trade was $6.39 \%$ in the same period. India's total export to China, its total imports from China, its growth rates and trade balance are shown in Table 1. Trends of India's exports to and its imports from China are also shown in Figure 1.

India's exports of principal commodities to China on a time series basis from 1998-99 to 200405 are shown in Table 2. Among other items, iron and ore are the single largest items of India's exports to China in 2004-05, though the trend has been increasing over the years. But these are the most important items in India's export basket followed by primary and semi-finished iron and steel, which are the second largest items that India exports to China. Other major product/product categories of India's export basket to China are: plastic \& linoleum products, processed minerals, inorganic/organic/agro chemicals, ores and minerals, drugs, pharmaceuticals and fine chemicals, machinery and instruments, residual chemicals \& allied products, non-ferrous metals, marine products, cotton yarn, fabrics and made up etc. A comprehensive list of India's major export items is shown in Table 2. 
Figure1: Trends in India's Trade with China

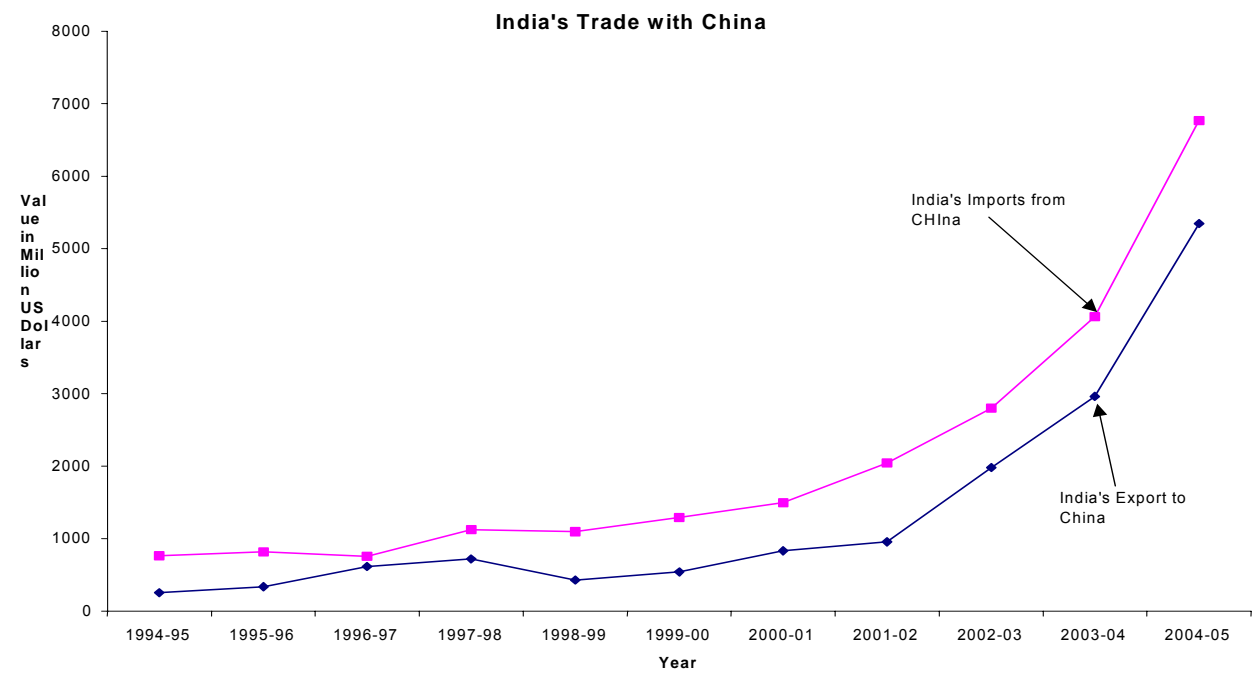

Table 1: India's Trade with China (Value in US \$ Million)

\begin{tabular}{|c|c|c|c|c|c|c|c|}
\hline Year & $\begin{array}{c}\text { India's Export } \\
\text { To China }\end{array}$ & $\begin{array}{c}\text { Rate of } \\
\text { Growth }\end{array}$ & $\begin{array}{c}\text { India's Imports } \\
\text { From China }\end{array}$ & $\begin{array}{c}\text { Rate of } \\
\text { Growth }\end{array}$ & Total Trade & $\begin{array}{c}\text { Growth of } \\
\text { Total Trade }\end{array}$ & $\begin{array}{c}\text { Trade } \\
\text { Balance }\end{array}$ \\
\hline $1994-95$ & 254.3 & & 761.04 & & 1015.34 & & -506.74 \\
\hline $1995-96$ & 333.2 & 31.03 & 813.19 & 6.85 & 1146.39 & 12.91 & -479.99 \\
\hline $1996-97$ & 615.32 & 84.67 & 757.55 & -6.84 & 1372.87 & 19.76 & -142.23 \\
\hline $1997-98$ & 718.94 & 16.84 & 1120.7 & 47.94 & 1839.64 & 34.00 & -401.76 \\
\hline $1998-99$ & 427.06 & -40.60 & 1096.47 & -2.16 & 1523.53 & -17.18 & -669.41 \\
\hline $1999-00$ & 539.41 & 26.31 & 1288.27 & 17.49 & 1827.68 & 19.96 & -748.86 \\
\hline $2000-01$ & 830.03 & 53.88 & 1494.92 & 16.04 & 2324.95 & 27.21 & -664.89 \\
\hline $2001-02$ & 955.19 & 15.08 & 2043.33 & 36.68 & 2998.52 & 28.97 & -1088.14 \\
\hline $2002-03$ & 1980.61 & 107.35 & 2799.29 & 37.00 & 4779.9 & 59.41 & -818.68 \\
\hline $2003-04$ & 2962.92 & 49.60 & 4063.96 & 45.18 & 7026.88 & 47.01 & -1101.04 \\
\hline $2004-05$ & 5344.88 & 80.39 & 6768.92 & 66.56 & 12113.8 & 72.39 & -1424.04 \\
\hline
\end{tabular}

Source: Monthly Statistics of Foreign Trade of India - DGCI\&S, Govt. of India 
Table 2: India's Exports of Principal Commodities to China (Value in US\$ Million)

\begin{tabular}{|l|c|c|c|c|c|c|c|}
\hline Name of the Commodities & $1998-99$ & $1999-2000$ & $2000-01$ & $2001-02$ & $2002-03$ & $2003-04$ & $2004-05$ \\
\hline Iron Ore & 87.77 & 81.43 & 130.16 & 207.56 & 409.37 & 825.74 & 2084.43 \\
\hline Prim. \& semi-fin.iron \&steel & 4.72 & 3.59 & 26.4 & 11.02 & 491.02 & 577.25 & 488.74 \\
\hline Plastic \& linoleum products & 6.28 & 25.36 & 103.11 & 141.95 & 177.92 & 306.44 & 438.9 \\
\hline Processed minerals & 16.99 & 11.56 & 15.24 & 23.4 & 87.58 & 99.99 & 230.85 \\
\hline Inorg/org/agro chemicals & 22.28 & 39.32 & 60.01 & 48.84 & 88.89 & 83.96 & 217.91 \\
\hline Other ores \& minerals & 39.93 & 65.47 & 73.15 & 113.81 & 154.3 & 128.88 & 192.48 \\
\hline Drugs, pharma.\& fine chem. & 42.68 & 46.01 & 58.56 & 80.37 & 93.02 & 102.53 & 106.33 \\
\hline Machinery \& instruments & 9.17 & 11.72 & 19.72 & 11.36 & 32.47 & 73.5 & 98.14 \\
\hline Residual chem. \& allied Prod & 6.42 & 8.5 & 11 & 16.75 & 21.45 & 33.89 & 76.77 \\
\hline Non-ferrous metals & 0.1 & 0.08 & 17.99 & 2.85 & 21.2 & 43.53 & 65.42 \\
\hline Marine products & 51.51 & 87.81 & 116 & 85.19 & 118.39 & 89.08 & 65.38 \\
\hline Cotton yarn fab madeups etc & 40.73 & 56.05 & 71.54 & 75.06 & 64.04 & 74.11 & 64.92 \\
\hline Electronic goods & 4.08 & 9.24 & 20.66 & 15.9 & 22.82 & 42.31 & 44.53 \\
\hline Castor oil & 17.19 & 31.95 & 13.83 & 7.08 & 1.64 & 8.93 & 40.89 \\
\hline Oil meals & 32.64 & 9.69 & 8.29 & 4.22 & 3.67 & 17.28 & 35.81 \\
\hline Finished leather & 3.32 & 4.02 & 8.41 & 12.7 & 15.84 & 21.65 & 30.5 \\
\hline Manufactures of metals & 3.79 & 1.41 & 10.57 & 11.5 & 32.31 & 27.9 & 28.95 \\
\hline Ferro alloys & 2 & 0.54 & 0.15 & 4.54 & 3.93 & 6.2 & 28.44 \\
\hline Dyes, intermediaries etc & 3.41 & 3.31 & 8.59 & 11.29 & 20.08 & 66.2 & 18.63 \\
\hline Gems \& jewelry & 1.27 & 0.31 & 0.17 & 0.66 & 2.08 & 9.73 & 18.45 \\
\hline All Commodities & 427.06 & 539.41 & 830.03 & 955.19 & 1980.61 & 2962.92 & 5344.88 \\
\hline
\end{tabular}

Source: Monthly Statistics of Foreign Trade of India - DGCI\&S, Govt. of India and Trade and Balance of Payment Statistics - CMIE, July 2005

Table 3 shows India's import of principal commodities from China from 1998-99 to 2004-05. India's major import items from China are electronic goods. Imports of these items have been consistently increasing over the years. Second largest imported items are coal, coke and lubricants. India imports substantial amount of coal from China, which suddenly shot up in 200405, though it was modest in the early years. Organic chemicals are the third largest import item from China in last several years. Other important import items are: non-electrical machinery, electrical machinery, medical and pharmaceutical products, textile yarn, fabrics and madeups, silk yarn and fabrics, non-ferrous metals, silver, iron and steel, inorganic chemicals, raw silk non-metallic manufactures, manmade filament/spun yarn/waste, metaliferrous ores and metal scrap etc. There are 20 major items in India's import basket from China which have been identified. This covers more than $80 \%$ of India's imports from China. Both in table $2 \& 3$, basic trends of bilateral trade between India and China of major commodities over the years are shown. Table 3 shows India's imports of principal commodities from China from 1998-99 to 2004-05. 
Table 3: India's Imports of Principal Commodities from China (Value in US\$ Million)

\begin{tabular}{|l|c|c|c|c|c|c|c|}
\hline Name of the Commodities & $1998-99$ & $1999-2000$ & $2000-01$ & $2001-02$ & $2002-03$ & $2003-04$ & $2004-05$ \\
\hline Electronic goods & 161.46 & 178.22 & 244.56 & 385.19 & 812.16 & 1384.44 & 2069.19 \\
\hline Coal, coke \& lubricants & 108.2 & 146.04 & 261.34 & 263.43 & 175.61 & 221.5 & 780.19 \\
\hline Organic Chemicals & 163.54 & 178.71 & 181.02 & 242.38 & 326.42 & 474.06 & 606.66 \\
\hline Non-electrical machinery & 48.92 & 53.04 & 60.49 & 72.14 & 105.69 & 184.38 & 424.43 \\
\hline Electrical machinery & 20.6 & 28.58 & 46.34 & 59.98 & 72.3 & 101.7 & 211.23 \\
\hline Medical \& Pharm products & 71.27 & 73.05 & 70.32 & 105.26 & 150.25 & 185.26 & 192.8 \\
\hline Other tex yarn, fab, madeups & & 20.5 & 34.75 & 46.89 & 75.97 & 107.66 & 172.95 \\
\hline Silk yarn \& fabrics & & 12.81 & 17.27 & 32.2 & 52.23 & 105.2 & 156.52 \\
\hline Non-ferrous metals & 52.27 & 49.01 & 41.89 & 54.53 & 46.23 & 86.82 & 145.13 \\
\hline Silver & & 20.16 & 8.3 & 94.41 & 121.21 & 58.42 & 138.62 \\
\hline Iron \& steel & 20.44 & 30.75 & 7.53 & 14.52 & 9.24 & 31.65 & 136.21 \\
\hline Inorganic chemicals & 62.72 & 53.2 & 48.37 & 59.66 & 69.25 & 104.46 & 131.22 \\
\hline Silk raw & 48.31 & 87.44 & 95.66 & 122.9 & 106.96 & 113.7 & 123.34 \\
\hline Non-metallic mineral mnfs. & 7.42 & 10.24 & 14.65 & 30.24 & 44.42 & 64.58 & 121.12 \\
\hline $\begin{array}{l}\text { Manmade filament/spun } \\
\text { yarn/waste }\end{array}$ & & 12.38 & 9.84 & 17.32 & 56.05 & 82.61 & 115.78 \\
\hline Metaliferrous ores \& metal scrap & 8.5 & 11.26 & 19.65 & 14.52 & 28.46 & 63.96 & 102.99 \\
\hline Professional inst, optical goods etc & 18.85 & 23.37 & 23.38 & 55.31 & 80.49 & 90.01 & 99.32 \\
\hline Transport equipment & 3.49 & 8.45 & 6.62 & 9.06 & 22.15 & 13.16 & 88.5 \\
\hline manufactures of metals & 12.04 & 15.38 & 17.77 & 31.14 & 32.69 & 55.34 & 88.07 \\
\hline All commodities & 1096.47 & 1288.27 & 1494.92 & 2043.33 & 2799.29 & 4063.96 & 6768.92 \\
\hline
\end{tabular}

Source: Monthly Statistics of Foreign Trade of India - DGCI\&S, Govt. of India, and Trade and Balance of Payment

Statistics - CMIE, July 2005

\section{Trade Intensity between India and China}

Apart from measuring the performance of bilateral trade in terms of growth rates, one can also measure the trade intensities between two countries to see the trajectory of trade over the years and the orientation of a country with its trading partner. Bilateral trade relationships between India and China described in terms of intensity indices help identify how intensively the countries are trading with each other. Trade intensity index is defined as the share of one country's trade with another country, divided by the other country's share of world trade. The value of index ranges from 0 to 100. If the value is 0 , it implies no trade relationship between partner countries. On the other hand, if the value of import intensity index is more (or less) than 100 , it indicates that country $i$ is importing more (or less) from country $j$ than might be expected from that country's share in total world trade. In export too, if the value is 0 or nearer to 0 , it implies export link between these two countries is negligible and if the value is nearer to 100 that indicates that performance is significant and if it exceeds 100 it indicates that country $i$ is exporting more to country $\mathrm{j}$ than might be expected from that country's share in world trade. 
The Import Intensity Index between India and China (MIlij) is shown as follows:

MIlij $=\left[M_{i j} / M_{i}\right] /\left[X_{j} /\left(X_{w}-X_{i}\right)\right]$

Where:

Mllij = Import intensity index of trade of country $i$ with country $j$

$\mathrm{Mij} \quad=$ Import of a country $\mathrm{i}$ to trading partner $\mathrm{j}$

$\mathrm{Mi} \quad=$ Total import of country $\mathrm{i}$

$\mathrm{Xj} \quad=$ Total export of country $\mathrm{j}$

$\mathrm{X} \mathrm{w}=$ Total world export,

$\mathrm{Xi} \quad=$ Total export of country $\mathrm{i}$

$\mathrm{i}, \mathrm{j} \quad=$ India and China

Export Intensity Index (XII) can also be measured as follows:

XIlij $=\left[X_{i j} / X_{i}\right] /\left[M_{j} /\left(M_{w}-M_{i}\right)\right]$

Where:

XIlij = Export intensity index of trade of country $\mathrm{i}$ with country $\mathrm{j}$

$X_{i j}=$ Export of country $\mathrm{i}$ to trading partner $\mathrm{j}$

$\mathrm{Xi} \quad=$ Total export of country $\mathrm{i}$

$\mathrm{Mj} \quad=$ Total import of country $\mathrm{j}$

$\mathrm{Mw}=$ Total world imports

$\mathrm{Mi} \quad=$ Total imports of country $\mathrm{i}$

$\mathrm{i}, \mathrm{j} \quad=$ India and China

Similar to India's import intensity index (XIlij) and export intensity index (XIlij) with China, import intensity index (MIlji) and export intensity index (XIIji) of China with India were also calculated. Export and import intensity indices of both India and China and vice-versa have been calculated from 1995 to 2005. The results are shown in Table 4.

Table: 4 Import and Export Intensity Indices of India and China, 1995-2005

\begin{tabular}{|c|c|c|c|c|}
\hline Year & MIIj & XIIij & MIIji & XIIji \\
\hline 1995 & 80.08 & 1.15 & 0.5 & 75.15 \\
\hline 1996 & 65.14 & 2.51 & 0.81 & 64.77 \\
\hline 1997 & 74.76 & 2.64 & 0.96 & 67.97 \\
\hline 1998 & 75.61 & 1.98 & 1.02 & 69.98 \\
\hline 1999 & 75.95 & 1.89 & 0.76 & 71.53 \\
\hline 2000 & 71.48 & 2.5 & 0.87 & 77.15 \\
\hline 2001 & 95.05 & 3.75 & 0.94 & 86.45 \\
\hline 2002 & 90.25 & 3.87 & 0.95 & 93.79 \\
\hline 2003 & 88.81 & 5.35 & 1.27 & 77.65 \\
\hline 2004 & 97.71 & 5.96 & 1.61 & 93.03 \\
\hline 2005 & 94.91 & 6.81 & 1.42 & 83.67 \\
\hline
\end{tabular}

Where $\mathrm{i}=$ India \& $\mathrm{j}=$ China

Table 4 indicates that India's export intensities to China have been extremely low over the years. India's export intensity index (XIlij) shows it is not only far below 100, but also it is hovering round the minimum value ranging 1.14 in 1995 to 6.81 in 2005. It indicates that India 
has been exporting extremely less to China all the years than what it ought to export. On the other hand, India's import intensity index with China is very high throughout the years though it is bellow 100. India's import intensity index was 80.08 in 1995, which increased to 94.91 in 2005 showing tremendous increase in India's imports from China.

Compared to India, China's import intensity index with India is very low over the years, which indicates China has been importing extremely less from India than what it should import. Therefore, there remains high potential for China to import more from India. China's import intensity index with India was 0.5 in 1995 that increased to 1.42 in 2005. Magnitude of import intensity index hovering round the minimum value of the index. On the other hand, China's export intensity index with India has been very high over the years though values are below 100. Its value was 75.15 in 1995, reached highest level of 93.79 in 2002 but dropped to 83.67 in 2005.

Therefore, it is revealed from the discussion above as well as from Table 4 that India exports much less to China market than what it should be and China imports much less from the Indian market than what it should be. Secondly, in both cases of imports and exports of India and China the values of indices are well bellow the desired level of 100 , which indicates that level of trade between India and China is not as high as it should be. Trade intensity index measures trade potentiality between two countries. If the index is below 100 then there is scope for mutual trade expansion between India and China, which can be achieved by suitable policy instruments. Therefore, there is enough scope for increasing bilateral trade between India and China. The trends of import and export intensity indices of both India and China are shown in the following figures 2 and 3.

Figure 2: India's Trade Intensity with China

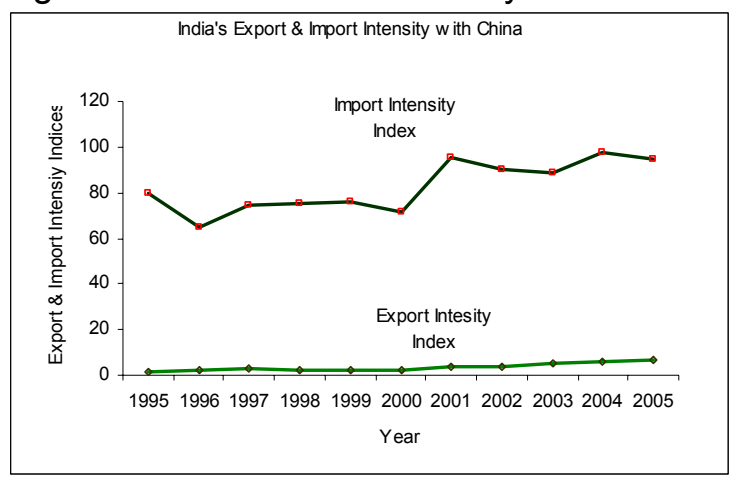

Figure 3: China's Trade Intensity with India

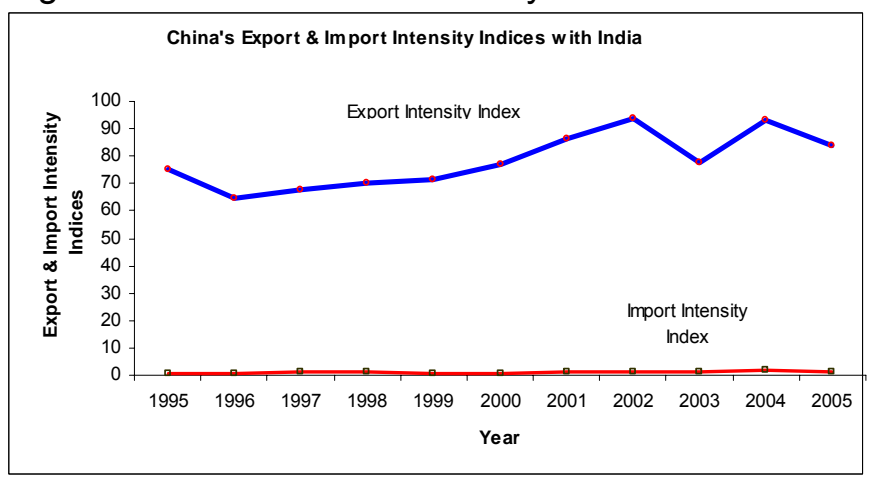

Apart from trade intensity index measuring trade potential, recently, there are host of studies available to measure the bilateral trade potentials using the gravity model. This model is popular these days because of its near accuracy in predicting bilateral trade flows. Some studies attempt to measure the impact of growth effect on trade using this model. The simple form the gravity model is as follows:

$X_{i j}=\alpha\left[\left(G D P_{i}^{*} G^{*} P_{j}\right)_{1}^{\beta} /\left(D_{i s t} t_{i j}\right)_{2}\right]$

Where $\mathrm{Xij}$ is bilateral trade between countries $\mathrm{i}$ and $\mathrm{j}$. Taking logarithms of the gravity model equation, one would get the linear form of the model i.e. 
$\log (X i j)=\alpha+\beta_{1} \log (G D P i * G D P j)-\beta_{2} \log ($ Distance $)$

Using this simple model to predict the bilateral trade flows between India and China emanating as a result of GDP growth, Batra (2004) has estimated the $\beta_{1}$ coefficient to be 0.87 . Boillot and Labbouz (2006) have shown that India and China's GDP growth induces bilateral trade growth of $\$ 3.1$ billion using data in 1990-2000. However, this figure compares with the current increase in bilateral flow of $\$ 4.9$ billion, which means that more than $60 \%$ of the actual growth of bilateral trade is explained by the economic growth effect. Using more variables into the main model several other estimations have been done predicting bilateral trade potentials. Using 1999-2000 data, Batra (2004) shows bilateral trade potential for India and China in 2000 was $\$ 7.6$ billion against the actual level of $\$ 2.9$ billion i.e. trade potential is 2.5 times higher than the actual trade. This large differential is due to exclusion of Hong Kong from China. Once Hong Kong is included, trade potential between these two countries becomes $\$ 8.6$ billion in 2000 against the actual trade flows of $\$ 5.7$ billion i.e. potential is higher than actual trade by about $30-35 \%$.

CRISIL (2003) has estimated the trade potential between India and China using coefficients estimated by others. Both Batra and CRISIL have used the gravity model and these two models are comparable. While Batra estimates the model for all countries of the world, CRISIL uses coefficients estimated by others for Latin American countries only and has used those coefficients to estimate trade potential between India and China. CRISIL estimation shows bilateral trade potential between India and China was $\$ 16$ billion in 2001 against actual trade of $\$ 4.2$ billion i.e. potential is 4 times higher than actual. CRISIL estimation is not much convincing in the sense that it has not included Hong Kong into the model and it has used Latin American model to estimate the trade potential between India and China. The cultural, geographic and commercial proximities between Latin American countries and India-China are significantly different. Trade potentials between India and China as estimated by different authors are shown in Table 5.

Table 5: Trade Potentials between India and China (in billion US\$)

\begin{tabular}{|l|c|c|c|}
\hline \multirow{3}{*}{ Year } & 2000 & & 2001 \\
\cline { 2 - 4 } & China & China $+\mathrm{HK}$ & China \\
\hline Actual Trade & 2.9 & 5.7 & 4.2 \\
\hline Trade Potential & 7.6 & 8.6 & 16 \\
\hline Gap & 4.5 & 2.9 & 11.8 \\
\hline Gap (\% of trade potential) & 59 & 34 & 26 \\
\hline
\end{tabular}

Source: Batra for trade potential estimation in 2000 for China only

CRISIL estimates for 2001 and Boillot estimates for 2000 including HK

\section{Assessing Likely Impact of PTAs and FTA between India and China}

Studies mentioned in the earlier section show that there has been enough potential to increase bilateral trade between India and China. There are several reasons why trade intensity between these two countries is so low and that explains the reason why trade potential between them is so high. All the reasons are grouped into two categories viz. (i) Objective resistance, and (ii) Subjective resistance (Garnaut, 1972). In case of objective resistance, trade intensity is likely to be very high if the combinations of the countries are between industrial goods exporter and primary product exporter. On the other hand, if the combination is between either industrial 
goods exporters or primary goods exporters then trade intensity will be low. Factors responsible for subjective resistance include discriminatory commercial policies, flow of capital and economic aid from the developed and developing countries etc. (Yamazawa, 1970). Due to nature of economies and structure of production, countries have limited scope to control over its objective resistance factors to enhance trade intensity, but, the countries can remove subjective resistance factors by cooperating with each other bilaterally or multilaterally and by encouraging regional cooperation though the formation of regional trading blocs (Kalirajan, 2000).

In this context the study is done to enhance bilateral trade by reducing trade resistance factors. However, in the short-run, the most important subjective factors that resist trade are tariff and non-tariff barriers to trade. Therefore, India's tariffs should be reduced to that level of China, at least, which should be the first step to enhance regional integration. The paper aims to make a hypothetical exercise measuring the impact of tariff reductions to bilateral trade between India and China. If tariff reductions are implemented through bilateral negotiations and in a phased manner then it must have a positive impact on intra-regional trade. Trade cooperation must start with PTAs with the objective of completely eliminating tariffs to facilitate FTA between these two countries, which is the ultimate objective of bilateral cooperation.

\section{IVa: Quantifying the Trade Impact: Analytical Framework, Data and Methodology}

Analytical tool for measuring the impact of PTAs and FTA on bilateral trade between India and China is the simple and extended version of the well-known gravity model used by Frankel et al. (1993). Quite a number of empirical studies are available quantifying the impact of tariff reductions on bilateral trade flows using the Gravity Model. The Gravity Model has been extensively used in the economic literature from the sixties onwards by Tinbergen (1962), Poyhonen (1963), Linnemann (1966), Anderson (1979) and others. In the eighties, Bergestrand $(1985,1989)$, Baldwin (1993), Deardorff (1998), Nilson (2000), Kalirajan \& Shand (1997), Kalirajan $(1999,2000)$ derived the Gravity Model from a general equilibrium framework where location of production and destination of market differentiate each product.

A number of different specifications of the Gravity Model have been used in the literature, depending mostly upon (i) the objective of the study, and (ii) type of the sample. In most of the existing studies, the bilateral trade flows have been explained by variables like GNP (proxy for size of countries), GNP per capita (proxy for degree of development), trade restrictive variables like tariff and non-tariff barriers, distance, adjacency, linguistic links, etc. In this paper, values were also taken on the elasticities (i.e. $a_{4}$ and $a_{5}$ ) estimated by Srinivasan and Canonero $(1993,1994,1995$ \& 1996), based on Gravity Model developed by Frankel (1993 \& 1997) and applied by Safadi and Yeats (1993), Ashfaque Khan (1996), Frankel and Wei (1995), Rajapakse and Arunatilake (1996), Somesh Mathur (2000), Mehta and Bhattacharya (1997, 1999 \& 2000), Bhattacharya $(2001,2003,2004,2005$ \& 2006) and Bhattacharya \& Kumar (2001). Srinivasan and Canonero (1995) estimated a gravity model, using rich data, but they gave emphasis to the intra-South Asia countries' trade under some hypothetical situations.

\section{IVb: The Scope and the Methodology}

The Gravity Model has a number of advantages in analyzing the intra-regional trade, particularly for the PTA of the nineties, sometimes known as "new regionalism".' Though it provides a good measure of trade creation, it has many limitations also. It does not take into account the possible impact of the terms of trade associated with trade creation. Hence the simulated 
results, based on the Gravity Model, are generally upward biased. The estimates also give the results in a static framework, and the extent of intraregional trade will possibly further increase if the estimation is carried out in a dynamic framework, incorporating the effects of factors like terms of trade, scale economies, technology spill-over, investment inflows, trade liberalization etc. These could reinforce the short term trade creation thus underestimating the true long-run impact. It is not possible to estimate the parameters related to some of these factors as the basic information to quantify all these is not available. As an example, some price elasticities could be approximated but information on scale economies simply does not exist. However, a number of existing studies have shown that the short-term impact is higher than the dynamic impact.

In addition, the results also do not take into consideration the concessions offered in the form of non-tariff barriers, it only considers reduction of tariffs under different scenarios, which is purely hypothetical. Thirdly, the results of alternate scenarios have also not measured the effect of PTAs/FTAs on different variables related to welfare." Even if the simulations correctly measure the impact on trade creation, it should be realized that this impact is not the only factor to take into account in evaluating FTAs. It is to be noted that the negative effect on bilateral trade with countries not entering in the simulated arrangement is not assessed in the simulations. Therefore, none of the indicators from the simulations could be viewed as a welfare measure, thus making the comparison of different scenarios rather incomplete. The results of the simulations presented here serve the limited purpose providing an estimate of the potential effects on bilateral trade between India and China based on a particular year data.

This paper mainly focuses on the likely increase in India-China trade under some hypothetical situations. In this analysis, the impact of PTAs by the proportionate change in exports and imports of India and China in dollar terms are basically measured. The higher the initial tariff level on trade between partners, the greater the final effect of reduction and elimination of tariffs. The result of reduction of tariffs would be reflected in increasing the estimated values of $a_{4} \& a_{5}$. However, tariff is only among many other factors that determine the impact of PTAs and FTA on trade. In assessing the impact, two other aspects should be kept in mind. First, the tariff $(1+$ $\left.T_{R, c}\right)$ i.e. $T_{R}=(1+$ percentage tariff of ' $d$ ') (where $d=$ China and $C=$ India), presents tariffs imposed by China on its imports from India. Similarly, the tariff $\left(1+T_{c, d}\right)$ i.e. TRc $=(1+$ percentage tariff of ' $c$ '), where TRc means tariffs imposed by India on its imports from China and TRd means tariff imposed by China on its imports from India. Since TRc (i.e. tariffs imposed by India on its imports from India) is higher than TRd (i.e. tariffs imposed by China), the higher the coefficient of TRc in absolute values, and the greater the impact of preferential arrangement. Secondly, since $a_{4}$ and $a_{5}$ are elasticities indicating the proportionate response of bilateral trade to changes in tariffs of China and India, the initial tariff levels as well as initial trade level are relevant for determining the absolute changes in trade in both India and China following PTAs/FTA.

In this paper, comparative static analysis of tariff reductions under different scenarios and its resultant effects on increase in imports and exports of both India and China were also done. The objective of this analysis is to examine the likely increase in intra-regional trade (measured in terms of higher rates of growth of exports and imports) of both the countries due to different PTAs and FTA. This paper deals with four hypothetical scenarios of PTAs and FTA between India and China, as follows:

(i) $25 \%$ across the board tariff cuts by India and China

(ii) $50 \%$ across the board tariff cuts by these two countries

(iii) $75 \%$ across the board tariff cuts by the same countries 
(iv) $100 \%$ tariff cuts i.e. free trade between them (i.e. between India and China)

\section{IVc: Data Sources}

This exercise is based on elasticities estimated by Srinivasan and Canonero using panel data. Frankel's estimation procedure is adopted in this model. The results of the simulations are not valid to any particular year; these are indicative due to reductions in tariffs under different hypothetical scenarios. Both tariffs and trade data used in this analysis are taken from TRAINS CD-ROM compiled by United Nations Conference on Trade and Development (UNCTAD). This study is based on trade and tariffs data for 2004. In the case of both India and China, mean tariffs were taken rather than weighted tariffs. Chinese tariffs data were taken from the World Development Indicators 2006 and Indian tariffs data were taken from the customs tariff manual 2004-05.

\section{IVd: The Model}

The Gravity Model developed by Frankel et al. (1993) and extensively used by Safadi and Yeats (1993) in their analysis to estimate the likely impact of the formation of the North American Free Trade Area on South Asia by considering other potential trading arrangements was determined to be the alternative. Following the above methodology, Srinivasan and Canonero(S-C) have estimated the effects of PTAs on South Asian countries. In this study, the model which was adopted by Srinivasan and Canonero $(1993,1994 \& 1997)$ was relied on. The main texture of the $\mathrm{S}-\mathrm{C}$ model is as follows:

$$
\begin{aligned}
& \log B_{c, d, t}=a_{0}+a_{1} \log \left(G N P_{c, t} * G N P_{d, t}\right)+a_{2} \log \left(\text { PCGNP }_{c, t}\right. \text { * } \\
& \left.\operatorname{PCGNP}_{d, t}\right)+a_{3} D_{c, d}+a_{4} \log \left(1+T R_{d, c}\right)+a_{5} \log \\
& \left(1+\operatorname{TR}_{c, d}\right)+a_{6} \log \operatorname{REXRT}_{c, d, t}+e_{c, d, t} \ldots \ldots \ldots \ldots(1)
\end{aligned}
$$

Where,

$\mathrm{BTI}_{\mathrm{c}, \mathrm{d}, \mathrm{t}}=$ Bilateral trade of commodity ' $\mathrm{i}$ ' between country ' $\mathrm{c}$ ' and country ' $\mathrm{d}$ ' at time ' $t$ '.

$\mathrm{GNP}_{\mathrm{c}, \mathrm{t}}\left(\right.$ or $\left.\mathrm{GNP}_{\mathrm{d}, \mathrm{t}}\right)=$ Gross National Product of country 'c' ( or 'd' ) at time $\mathrm{t}$

PCGNP $_{c, t}$ (or, PCGNPd, ${ }_{t}$ ) = Per capita Gross National Product of country 'c' or country ' $d$ '.

$D_{c, d}=$ Distance between relevant centers of ' $c$ ' on country ' $d$ '.

$\mathrm{TR}_{\mathrm{c}, \mathrm{d}} \quad=$ Tariff rate imposed by country ' $\mathrm{c}$ ' on products imported from country ' $d$ '.

$\mathrm{TR}_{\mathrm{d}, \mathrm{c}} \quad=$ Tariff rate imposed by country 'd' on products imported from country 'c'.

$\operatorname{REXRT}_{c, d, t} \quad=$ Real Effective Exchange Rate between countries ' $c$ ' and ' $d$ ', at time ' $t$ '.

$\mathrm{u}, \mathrm{v} \quad=$ country specific effect

$\mathrm{W} \quad=$ temporal effect

$\eta \quad=$ random effects

$\mathrm{c}, \mathrm{d}=$ India, China, and

$\mathrm{e}_{\mathrm{c}, \mathrm{d}, \mathrm{t}} \quad=\mathrm{u}_{\mathrm{c}}+\mathrm{v}_{\mathrm{d}}+\mathrm{w}_{\mathrm{t}}+\eta_{\mathrm{c}, \mathrm{d}, \mathrm{t}}$

The signs of the coefficients are different which indicates different directions of the parameters. Intuitive results are that trade between two equal size countries will be greater than between 
one large and one small economies. This observation is also consistent with the objective resistant factors, which says that trade intensity between two countries is likely to be high if the combination of countries are between industrial good exporter and primary good exporter. On the other hand, if the combination is between either industrial good exporter or primary good exporter, the intensity will be low. Therefore, ' $a_{1}$ ' of equation (1) will be positive. Both distance and tariff barriers restrict trade flows between two countries. Therefore, coefficients $a_{3}, a_{4}, \& a_{5}$ will be all negative. The effect of real exchange rate on total trade is ambiguous, but this variable is taken to serve as "catch-all" proxi-variable for other fundamental changes not included in other variables.

Panel data are used in this model, the utilization of which requires special treatment of the error terms shown in equation (1). A more general expression of the error term ' $e_{c, d, t}$ ' can be written as follows:

$e_{c, d, t}=u_{c}+v_{d}+w_{t}+\eta_{c, d, t} \ldots \ldots \ldots(2)$

Where,

$u \& v=$ country specific effects

$\mathrm{w} \quad=$ temporal effects, and

$\eta \quad=$ random effects

In equation (2), one can avoid consistency problems arising from country-specific effects by estimating equation (1) with its variables defined as deviations from their individual means. But this is not the reasonable proposition simply because of the fact that the effects of PTAs and FTA are being evaluated, and therefore, one should know the values of the tariff variables viz. $\left(1+T R_{c, d}\right) \&\left(1+T R_{d, c}\right)$, which are eliminated from the estimated equation, once the variables are expressed as deviation from their means (Srinivasan and Canonero 1993)

After estimating all parameters in equation (1), one can estimate the parameters of variance component model of equation (2). The problem of using country dummies will be solved if ' $u$ ' and ' $v$ ' are fixed effects. But if these effects are random, the more appropriate way to estimate equation (1) would be by using Generalized Least Square (GLS), taking into consideration of the variance of country-specific effects to the variance of $e_{c, d, t}$. The possibility of correlation between individual country effects and the explanatory variables can be tested through the appropriate test for the exogeneity of explanatory variables with an object to see the instrumental variables are really needed. Since preliminary estimation of equation (1) using country dummies shows that the assumption of fixed effect is inappropriate, but the results from this estimation still show the presence of individual effects. Therefore, equation (1) is reestimated assuming random effects, using lags of GNP and GNPPC as instruments and tested for their exogeneity (Srinivasan and Canonero 1993). Variables like GNP \& GNPPC are correlated with the error terms because BTI (i.e. bilateral trade between India and China) is the sum of exports and imports, instrumental variables should be used in the particular case. But the normal practice is to use OLS for estimating the equation.

Further, the variance-component regression model has been adopted to capture the spatial impact of individual countries ( $u$ and $v$ ) and time period ( $t$ ). Although the model used by Srinivasan and Canonero captures the impact of country characteristics and temporal effects through variance components, and are estimated for the commodity groups relevant to South Asia. iii This model has number of limitations. The simulations were based on the same tariff rate 
for all the 9 commodity groups. Further, the estimation of the Variance Component Model is carried out using data for incomplete panels, i.e. missing observations. But, the estimation procedure does not seem to capture the features of incomplete repeated samples. The estimation of Variance Component Model for incomplete panels has been examined in the literature by Bi申rn (1981), Wansbeek and Kapteyn (1989) and others. In spite of all these limitations, the fitted regression equations of 8 commodity groups are very satisfactory. Some of the relevant parameters of the regression equation, used in the simulations, are reported below, for ready reference.

The essence of the Gravity Model is that the bilateral trade flow is positively related to the size of the two countries and inversely related to the distance between them. This follows the concept of physical science, where gravity force is directly proportional to the mass of two bodies and inversely proportional to the distance between them. ${ }^{\text {iv }}$ The regression results are presented in Table 6 . In the analysis, instrumental variables with random effects were taken. In table, T1 is ' $a_{4}$ ', whose value is 3.9 , which is the coefficient of $\left(1+T R d_{d}\right)$ and T2 is ' $a_{5}$ ' whose value is 4.66 , which is the coefficient of tariffs imposed by India on its imports from China i.e. $\left(1+\mathrm{TR}_{\mathrm{c}, \mathrm{d}}\right)$.

Table 6: Regression Results (Total Trade)

A. Instrumental Variables - No Panel Features

\begin{tabular}{|l|c|c|c|}
\hline Variables & Coefficient & $\begin{array}{c}\text { Std. } \\
\text { Error }\end{array}$ & T-Stat \\
\hline GNP & 0.73 & 0.02 & 42.34 \\
\hline GNPPC & 0.33 & 0.02 & 14.85 \\
\hline D & -0.81 & 0.05 & -17.28 \\
\hline T1 & -5.74 & 0.42 & -13.83 \\
\hline T2 & -5.45 & 0.38 & -14.38 \\
\hline REXR & 0.79 & 0.09 & 8.41 \\
\hline Constant & \multicolumn{2}{|l|}{} \\
\hline$R^{2}=0.54$ & -22.00 & 0.82 & -26.71 \\
\hline
\end{tabular}

Analysis of Variance:

\begin{tabular}{|l|r|r|r|r|}
\hline Source & $\begin{array}{l}\text { Sum of } \\
\text { Squares }\end{array}$ & Degrees & $\begin{array}{l}\text { Mean } \\
\text { Sqrs }\end{array}$ & F-Static \\
\hline INDIV & 15259.15 & 217.00 & 70.32 & 24.40 \\
\hline ERROR & 14286.36 & 4957.00 & 2.88 & \\
\hline TOTAL & 29545.50 & 5174 & & \\
\hline
\end{tabular}

B. Instrumental Variables - Random Effects

\begin{tabular}{|l|r|r|r|}
\hline Variables & Coefficient & \multicolumn{1}{c|}{$\begin{array}{c}\text { Std. } \\
\text { Error }\end{array}$} & \multicolumn{1}{c|}{ T-Stat } \\
\hline GNP & 0.83 & 0.05 & 15.79 \\
\hline GNPPC & 0.01 & 0.09 & 0.12 \\
\hline D & -1.08 & 0.17 & -6.37 \\
\hline T1 & -3.90 & 1.55 & -2.52 \\
\hline T2 & -4.66 & 1.19 & -3.91 \\
\hline REXR & 0.88 & 0.07 & 11.77 \\
\hline Constant & -19.16 & 2.49 & -7.69 \\
\hline
\end{tabular}




$$
\begin{gathered}
\mathrm{R}^{2}=0.007, \mathrm{R}^{2} \text { Adj. }=0.007, \mathrm{DW}=1.23, \text { WALD Test: } \mathrm{F}(7)=2159, \text { Significance } \\
\text { Level }=0.000
\end{gathered}
$$

\section{IVe: The Methodology}

For estimating the increase in imports of both India and China, elasticities estimated by Srinivasan and Canonero were used. The elasticities estimated by Srinivasan \& Canonero are given in Table 7. Coefficient " $a_{5}$ " is relevant while estimating gains from China's exports to India at different levels of desegregation as well as total exports, since this is the tariff coefficient applicable to India's imports from China at different tariff levels. Whereas coefficient " $a_{4}$ " is the coefficient of different tariff levels ( i.e. $1+T R_{d, c}$ ) applicable to China's imports from India due to PTAs and FTA. While estimating likely increase in India's imports from China and vice-versa in value terms, the Variance Component Model was used. The entire commodities at 8-digit level are grouped into nine major groups in terms of importance in exports and imports of the South Asian region. Srinivasan and Canonero have done this exercise by using panel data. The groups and corresponding elasticities are shown in Table 8.

\section{Table 7: Elasticities of Major Commodities}

\begin{tabular}{|c|l|c|c|}
\hline Group No. & Commodity Groups & $\mathbf{~ ‘}_{4}{ }^{\prime}{ }^{\prime}$ & $\mathbf{~} \mathbf{a}{ }^{\prime}$ \\
\hline I & Total Trade & -3.9 & -4.66 \\
\hline I & Coffee, tea, coca \& spices & -5.81 & -0.43 \\
\hline II & Textile fiber & -15.38 & -7.78 \\
\hline III & Fuels & -3.83 & -8.15 \\
\hline IV & Non-fuel primaries(except covered in I\&II) & -4.76 & -6.0 \\
\hline V & Leather, dressed, fur etc & -2.08 & -2.73 \\
\hline VI & Textile yarn, fabrics etc & -5.16 & -4.31 \\
\hline VII & Machine \& transport equipment & -3.45 & -3.14 \\
\hline VIII & Clothing & -2.41 & -10.03 \\
\hline IX & Other manufactures & -4.66 & -4.77 \\
\hline
\end{tabular}

Given the estimated parametric value of ' $a_{4}$ ' and ' $a_{5}$ ' from the fitted regression equations (of the nine commodity groups), and changes in tariff rates under different alternative scenarios, the percentage increase in import from $d$ to $c$ (i.e. from China to India) and percentage increase in exports from c to d (i.e. India to China) were worked out. The methodology is:

$\left[\exp \left\{\hat{a}_{4} \log \left(\left(1+\mathrm{TR}_{\mathrm{d}, \mathrm{c}}\right)_{1} /\left(1+\mathrm{TR}_{\mathrm{d}, \mathrm{c}}\right)_{0}\right)+1 / 2 \sigma^{2}\right\}-1\right] * 100$

an increase of import of $d$ from c (i.e. imports from India to China)

$\left[\exp \left\{\hat{a}_{5} \log \left(\left(1+\mathrm{TR}_{\mathrm{c}, \mathrm{d}}\right)_{1} /\left(1+\mathrm{TR}_{\mathrm{c}, \mathrm{d}}\right)_{0}\right)+1 / 2 \sigma^{2}\right\}-1\right.$ ] 100

an increase of exports from $c$ to $d$ ( i.e. from India to China)

where,

$\sigma^{2}=\sigma^{\wedge}{ }_{a}^{2} 4 \log (1+T R d, c)+a 5 \log (1+T R c, d)$

The elasticities used in these simulations are higher than what it expected to be. The reasons are as follows: a) these are tariff elasticities not the price elasticities showing the increasing in 
demand due to reduction in preferential tariffs. In this case $1+T R$ is the most appropriate method to estimate the increase in trade due to reduction in tariff rather than on price. b) Elasticities (1+TR) are higher basically due to distance factor. It is also empirically true that price elasticity is inversely related to distance. If the distance is less, obviously elasticity becomes higher than the commodities imported by India from USA and Europe where there is less elasticity due to distance factor.

\section{Simulation Results}

The present study is a comparative-static analysis showing the tentative increase in bilateral trade due to PTAs and FTA between India and China. The results are hypothetical and indicative not actual one. This study gives an indication how and to what extent tariffs should be reduced both by China and India and most importantly what should be the direction of regional economic integration with the clear objective of concluding FTA between these two countries. Since India and China are yet to sign FTA and is possibly long way to do that, any estimation on the gains and losses of bilateral trade due to PTAs and FTA is not possible unless the schedule of programs to be agreed upon by both the countries are known. Despite this fact, in a given situation, one can simulate the likely increase in bilateral exports and imports due to PTAs and FTA based on current levels of tariffs, which will make policy makers aware of the consequences of liberalization of tariffs. While simulating the impact of PTAs and FTA, products/product groups beyond 2-digit HS levels were not taken for the sake of convenience. In the case of China, tariff information from TRAINS CDROM compiled by UNCTAD at the 2digit HS categories were taken. Average MFN tariffs of China at the 8 digit levels and then aggregated into 2 digit levels totaling about 97 product groups were also taken. Both tariffs and trade data are taken for the year 2004 for both the countries. India's tariff data were taken from the Customs Tariff Manual for 2004-2005. In India's case, trade and tariff data are available at 8-digit HS categories, which have been aggregated to 20 major categories of items for simulation purposes. India's imports from China are taken from the Monthly Statistics of Foreign Trade of India and China's imports from India are taken from COMTRADE Statistics published by the UN Statistical Division.

In the simulation exercise, four kinds of hypothetical scenarios were taken into account. The simulation results are very much consistent with a priori idea that the country, whose tariffs are low, will gain much than the country whose tariffs are high. In the exercise, China's simple average mean tariff was $9.8 \%$ in 2004 and India's simply average mean tariff was $28.3 \%$ in the same period i.e. $199 \%$ higher than India's mean tariffs. Such huge difference in tariff structure is reflected in the simulation results. If both India and China go for PTAs and FTA, the likely increase in bilateral exports and imports are shown in Table 8 \& 9. Table 8 shows likely increase in India's imports from China if India's existing tariffs are reduced by $25 \%, 50 \%, 75 \%$ and $100 \%$ i.e. duty free. 
Table 8: Likely Increase in India's Imports from China under different PTAs and FTA

\begin{tabular}{|c|c|c|c|c|c|c|c|c|c|c|}
\hline \multirow[t]{2}{*}{ Name of the Commodities } & \multirow{2}{*}{$\begin{array}{c}\text { India's } \\
\text { Imports } \\
\text { from China } \\
\text { (2004) } \\
\text { Million \$ }\end{array}$} & \multirow{2}{*}{$\begin{array}{c}\text { MFN Tariff } \\
\text { (Ave) of India } \\
\text { (2004) }\end{array}$} & \multicolumn{4}{|c|}{$\begin{array}{l}\text { Increase in India's Imports from China (US \$ } \\
\qquad M n .)^{\star}\end{array}$} & \multicolumn{4}{|c|}{$\begin{array}{c}\text { Increase in India's Imports from China } \\
\text { (Percentage) }\end{array}$} \\
\hline & & & $\underset{I^{\star \star}}{\text { Scenario }}$ & $\begin{array}{l}\text { Scenario } \\
\text { II }\end{array}$ & $\begin{array}{c}\text { Scenario } \\
\text { III }\end{array}$ & Scenario IV & $\begin{array}{c}\text { Scenario } \\
I\end{array}$ & $\begin{array}{c}\text { Scenario } \\
\text { II }\end{array}$ & $\begin{array}{l}\text { Scenario } \\
\text { III }\end{array}$ & $\begin{array}{l}\text { Scenario } \\
\text { IV }\end{array}$ \\
\hline Electronic Goods & 2069.19 & 40.37 & 996.13 & 1992.27 & 2988.4 & 3984.53 & 48.14 & 96.28 & 144.24 & 192.56 \\
\hline Coal, coke \& lubricants & 780.19 & 27.84 & 442.55 & 885.11 & 1327.66 & 1770.22 & 56.72 & 113.45 & 170.17 & 226.9 \\
\hline Organic chemicals & 606.66 & 34.44 & 3113.4 & 626.8 & 940.2 & 1253.6 & 51.66 & 103.22 & 154.98 & 206.64 \\
\hline Non-electrical machinery & 424.43 & 40.37 & 134.5 & 269.01 & 403.51 & 538.02 & 31.69 & 63.38 & 95.07 & 126.76 \\
\hline Electrical machinery & 211.23 & 40.37 & 66.94 & 133.88 & 200.82 & 267.76 & 31.69 & 63.38 & 95.07 & 126.76 \\
\hline $\begin{array}{l}\text { Medical \& pharmaceutical } \\
\text { products }\end{array}$ & 192.8 & 40.37 & 92.82 & 185.63 & 278.45 & 371.27 & 48.14 & 96.28 & 144.42 & 192.56 \\
\hline Other text. yarn fab, madeups & 172.95 & 30.38 & 56.61 & 113.23 & 169.84 & 226.46 & 32.73 & 65.47 & 98.2 & 130.94 \\
\hline Silk yarn \& fabrics & 156.52 & 30.38 & 51.24 & 102.47 & 153.71 & 204.94 & 32.73 & 65.47 & 98.2 & 130.94 \\
\hline Non-ferrous metals & 145.13 & 34.44 & 74.97 & 149.95 & 224.92 & 299.9 & 51.66 & 103.32 & 154.98 & 206.64 \\
\hline Silver & 138.62 & 20.4 & 42.42 & 84.84 & 127.25 & 169.67 & 30.6 & 61.2 & 91.8 & 122.4 \\
\hline Iron \& steel & 136.21 & 58.27 & 94.65 & 189.3 & 283.94 & 378.59 & 69.49 & 138.97 & 208.46 & 277.95 \\
\hline Inorganic chemicals & 131.22 & 40.37 & 79.46 & 158.92 & 238.38 & 317.84 & 60.56 & 121.11 & 181.67 & 242.22 \\
\hline Silk raw & 123.34 & 30.6 & 73.41 & 146.82 & 220.22 & 293.63 & 59.52 & 119.03 & 178.55 & 238.07 \\
\hline Non-metallic mineral mnfs & 121.12 & 20.4 & 29.46 & 58.93 & 88.39 & 117.86 & 24.33 & 48.65 & 72.98 & 97.31 \\
\hline $\begin{array}{l}\text { Manmade filament/spun yrn/ } \\
\text { waste }\end{array}$ & 115.78 & 40.37 & 50.36 & 100.73 & 151.09 & 201.45 & 43.5 & 87 & 130.5 & 173.99 \\
\hline Metaliferrous ores \& metal scrap & 102.99 & 58.27 & 90.02 & 180.04 & 270.06 & 360.07 & 87.41 & 174.81 & 262.22 & 349.62 \\
\hline Professional instmt. Optical goods & 99.32 & 40.37 & 31.47 & 62.95 & 94.42 & 125.9 & 31.69 & 63.38 & 95.07 & 126.76 \\
\hline Transport equipment & 88.5 & 40.37 & 28.05 & 56.09 & 84.14 & 112.18 & 31.69 & 63.38 & 95.07 & 126.76 \\
\hline Manufactures of metals & 88.07 & 40.37 & 42.4 & 84.8 & 127.19 & 169.59 & 48.14 & 96.28 & 144.42 & 192.56 \\
\hline All Commodities & 6768.92 & 28.3 & 2231.68 & 4463.36 & 6695.04 & 8926.72 & 32.97 & 65.94 & 98.91 & 131.88 \\
\hline
\end{tabular}

* Simulation results are based on Gravity Model, the methodology of which has been spelt out in the earlier section, Values are in Million US \$

** Scenario I = $25 \%$ tariff cut, Scenario II =50 \% tariff cut, Scen III = $75 \%$ tariff cut, \& Scenario IV = 100 tariff cut or duty free import

Source: Monthly Statistics of Foreign Trade of India - DGCI\&S, Govt. of India, Trade \& Balance of Payment Statistics - CMIE, July 2005, TRAINS - UNCTAD

Customs Tariff Manual, 2005 - Ministry of Commerce, Govt. of India 
Table 8 depicts the simulation results, based on the gravity model, of likely increase in India's imports from China under different scenarios. In this table, there are major 20 commodities in order of trade coverage, whose combined share is more than $80 \%$ of India's total imports from China during that period. In 2004-05, India's average MFN tariff was $28.3 \%$, which is taken from the World Development Indicators 2006. The average tariffs of all commodities from the Customs Tariff Manual, Govt. of India have been calculated. India's major import items from China in 2004 were electronic goods, coal, coke \& lubricants, organic chemicals, electrical and non-electrical machinery, medical and pharmaceutical products, textile and silk yarn etc. As it is mentioned earlier that due to PTAs and FTAs, the country will gain much whose initial tariff level is much lower than its competitors and vice-versa. Since India's average tariff level was $28.3 \%$ compared to China's 9.8\%, India's increase in imports from China will be much more than latter's imports from the former. Simulation results show that if India's offers $25 \%$ tariff reductions on all of its imports from China, its total imports from the latter country will increase by $31.97 \%$ and if such reductions are extended to $50 \%$ across the board, its imports from China will be increased by $65.94 \%$. If there is FTA between these two countries, India's imports from China will be increased by $131.88 \%$.

Commodity wise brake up of the impacts of PTAs and FTA is shown in the same table. Electronic goods rank first among twenty products/product groups imported by India from China in 2004. If there is FTA, India's total imports of electronic goods from China will be increased by $192.56 \%$ and the increased of imports of the second largest group i.e. coal \& lubricants will be increased by $226.9 \%$. The simulation results also show that imports of organic chemicals will be increased by $206.64 \%$ and electrical and non-electrical machineries will be increased by $126.76 \%$. Estimated increase in imports will be highest in the group of metaliferrous ores and metal scrap, whose imports will be increased by $349.62 \%$ due to FTA; the trends are same in case of PTAs also. Other important product/product groups whose imports will be significantly increased are: medical and pharmaceutical products, non-ferrous metals, articles of iron and steel, inorganic chemicals and raw silk. In all these categories, likely increase in imports from China will be more than $200 \%$. In other categories too, imports will be increased significantly due to FTA and PTAs. The entire scenarios or likely increased in India's imports of China due to PTAs and FTA are shown in Table 8. The table also shows likely increase in imports in value terms, which is expressed in million US Dollars in all categories as well as total imports based on 2004 import data.

In table 9, the likely increase in China's imports from India due to several PTAs and FTA are shown. The values are expressed in thousand US Dollars ('000 US\$), rather than million in the case of India. The simulation results based on gravity model show that due to FTA, China's total imports from India will be increased by $38.22 \%$ only as against India's increase of $131.88 \%$. The differences in imports are due to differential tariffs existed in both the countries. If China offers $25 \%$ reduction in its existing tariffs on all of its imports from India, its imports will be increased by $9.56 \%$ only against India's increased of $32.97 \%$. If China offers $50 \%$ and $75 \%$ reduction in tariffs on all goods imported from India, its imports will be increased by $19.11 \%$ and $28.67 \%$ respectively, much lower compared to India's increase in imports from China. Table 9 also shows China's likely increase in imports from India in value terms. 
Table 9: Likely Increase in China's Imports from India (India's Exports to China) under different PTAs and FTA, 2004

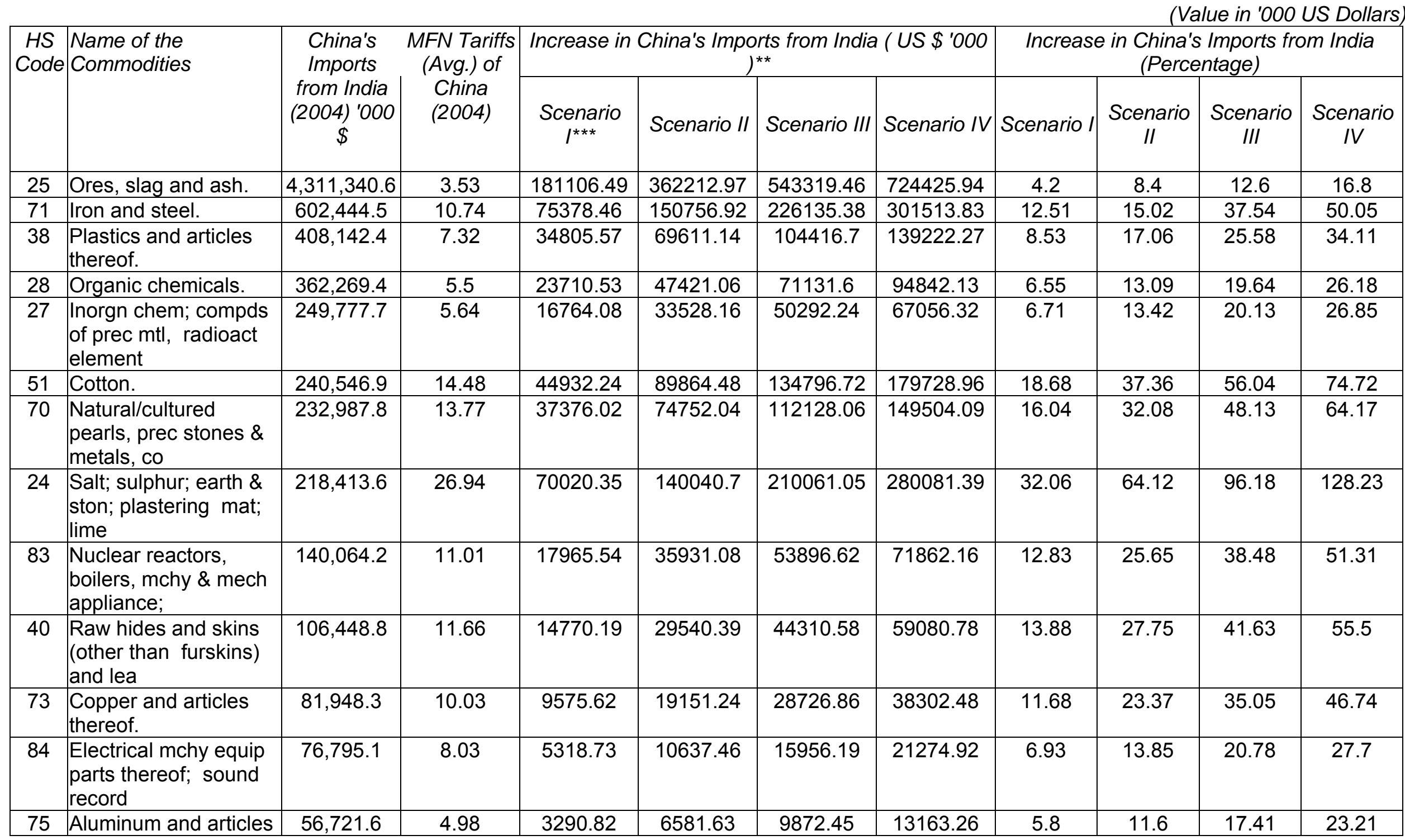




\begin{tabular}{|c|c|c|c|c|c|c|c|c|c|c|c|}
\hline \multicolumn{12}{|c|}{ thereof. } \\
\hline 65 & $\begin{array}{l}\text { Prepr feathers \& } \\
\text { down; arti flower; } \\
\text { articles huma }\end{array}$ & $48,773.4$ & 17.07 & 9699.35 & 19398.71 & 29098.06 & 38797.42 & 19.89 & 39.77 & 59.66 & 79.55 \\
\hline 2 & $\begin{array}{l}\text { Fish \& crustacean, } \\
\text { mollusc \& other } \\
\text { aquatic invert }\end{array}$ & $47,354.0$ & 18.57 & 10464.42 & 20928.85 & 31393.27 & 41857.7 & 22.1 & 44.2 & 66.29 & 88.39 \\
\hline 39 & $\begin{array}{l}\text { Rubber and articles } \\
\text { thereof. }\end{array}$ & $44,695.1$ & 8.94 & 4655.04 & 9310.08 & 13965.12 & 18620.17 & 10.42 & 20.83 & 31.25 & 41.66 \\
\hline 89 & $\begin{array}{l}\text { Optical, photo, cine, } \\
\text { meas, checking, } \\
\text { precision, }\end{array}$ & $42,237.3$ & 7.56 & 3720.01 & 7440.01 & 11160.02 & 14880.03 & 8.81 & 17.61 & 26.42 & 35.23 \\
\hline 30 & $\begin{array}{l}\text { Tanning/dyeing } \\
\text { extract; tannins \& } \\
\text { derivs; pigm et }\end{array}$ & $41,018.9$ & 4.81 & 2347.88 & 4695.76 & 7043.64 & 9391.52 & 5.72 & 11.45 & 17.17 & 22.9 \\
\hline 22 & $\begin{array}{l}\text { Residues \& waste } \\
\text { from the food indust; } \\
\text { prepr ani }\end{array}$ & $40,563.3$ & 26.75 & 12912.30 & 25824.6 & 38736.9 & 51649.2 & 31.83 & 63.67 & 95.5 & 127.33 \\
\hline 11 & $\begin{array}{l}\text { Oil seed, oleagi fruits; } \\
\text { miscell grain, seed, fru }\end{array}$ & $38,761.3$ & 26.78 & 15077.34 & 30154.67 & 45232.01 & 60309.35 & 38.9 & 77.8 & 116.69 & 155.59 \\
\hline & All Commodities & $7,678,030.1$ & 9.8 & 733635.78 & $1467271 . .56$ & 2200907.34 & 2934543.12 & 9.56 & 19.11 & 28.67 & 38.22 \\
\hline
\end{tabular}

*Values mentioned in this column are China's imports from India in 2004. Total value of 20 major commodities mentioned above covers $96 \%$ of total China's imports from India during that period. The reason to mention India's exports to China is to make a comparison between India's imports from and exports to China. Tariffs are average MFN tariffs of China in 2004.

** The simulations are based on gravity model. Detailed methodology of the estimation of gravity model is shown in the text. The elasticities of these commodities are taken from Srinivasan and Canonero study, which are also mentioned in the text.

${ }^{* * *}$ Scenario I $=25 \%$ tariff cut, Scen. II $=50 \%$ tariff cut, Scen III = $75 \%$ tariff cut, and finally Scenario IV $=100 \%$ tariff cut or duty free imports

Source: Both trade and tariff data are taken from TRAINS, compiled by UNCTAD 
China's largest import items from India were ores, slag \& ash at the 2 digit HS category 24, which was around $\$ 4.3$ billion in 2004 , followed by iron \& steel whose import was $\$ 602$ million. The simulation results show that if China offers duty free treatment (FTA) to India, its imports of this category (i.e. HS 25) would increase only by $16.8 \%$. Such very low level increase is because China has almost negligible tariff in this category, which was $3.53 \%$ in 2004 . In most of the items of these categories, tariff levels are zero or so at the 6 digit levels. Tariff levels become high once the items are processed from primary to intermediary stage. If China completely eliminates tariffs on its imports from India, highest increase in imports is noticed in category 11 i.e. oil seed, oleagi fruits, fruits and miscellaneous grain category, whose imports would increase by $155.59 \%$ followed by residue \& waste from the from industry (HS 22), whose imports would increase by $127.33 \%$. Other major items, whose imports would increase significantly due to FTA are cotton (HS 51), natural/cultured pearls, precious stones and metals (HS 70), salt, sulphur, earth \& stone, plastic materials and lime (HS 24), raw hides \& skins and leather (HS 40), articles of feather, flowers etc (HS 65), fish \& crustacean, mollusk \& other aquatic invertibles (HS 2) etc. Imports of these items from India will be increased by $74.72 \%$, $64.17 \%, 128.23 \% 55.5 \%, 79.55 \%$ and $88.39 \%$ respectively. Both value and percentage terms of China's increase in imports from India under different scenarios are shown in Table 9. Due to FTA, China's imports are not very significant in three categories viz. ores, slag and ash (HS 25), electrical machinery, equipments and parts (HS 84), and finally tanning and dyeing materials (HS 30). In these categories import growth is less than 30\%, with the lowest of $16.8 \%$ in ores, slag and ash categories because of its lowest tariffs than all products imported by China from India.

Another important feature of trade between India and China has been the composition of items imported by both countries. While India imports basically finished and manufactured products and less of primary and intermediary products, on the contrary, China imports basically primary and intermediary products from India with least of finished products. India's commodity concentration in imports from China is very high on manufactured goods; on the other hand, China's commodity concentration of imports from India is very high on primary and intermediary goods. Due to China's nature of products imported from India, tariff levels are very low. Therefore, imports are unlikely to be very high due to PTAs and FTA. On the other hand, most of India's imported items from China are manufactured goods and finished products, whose tariff levels are very high compared to primary goods. Therefore, any reduction in tariff will increase its imports substantially. It is concluded that any kind of bilateral PTA or FTA, India will not gain much at least in the short run unless there is a substantial change in investment regime first to make India more competitive with China, and second, India should put its tariffs at par with China.

Simulation results show the likely increase in India's imports from China and latter's imports from the former due to PTAs and FTA. The percentage is notional in the sense that increases in value of exports and imports depend on the base values of both way trade. In 2004-05, India registered an export growth of $80.87 \%$ to Chinese market whereas its import growth was $67 \%$ only, which was much less than exports. It is expected that if India and China decide to go for free trade, apart from the items presently traded, host of other new items will be traded between them which were not traded earlier. Trade depends on many other factors other than tariffs. In the simulation exercise, only reduction of tariffs under cetrisperibus assumption was taken.

\section{Concluding Observations}

Chinese President Hu Jintao said during his visit to India in November 2006 "Asia will dominate next century if China and India can strengthen their trade and business links". There are enormous and manifold opportunities. A joint study group, established by heads of both 
governments completed the preparation of a report in April 2005. The report identified potential complementarities between India and China in expanded trade and economic ooperation recommended a series of measures to facilitate bilateral trades in good, services, investments etc based complementarities between two countries. The discussions at the Ministerial-level Joint Economic Group in New Delhi on March 16, 2006 showed a determination for further development of the bilateral trade and economic relationship in next five years. Business leaders in both countries are identifying opportunities for cooperation in many areas, including energy. On 21 November 2006, India and China agreed to double the trade between two countries to US $\$ 40$ billion by 2010 .

India and China are two largest and fastest growing economies in Asia. FTA between India and China certainly goes in favor of China and it is disadvantageous to India at least in the short run. This is because of high tariff regime in India and low tariff regime in China. FTA between India and China may hurt economic efficiency between the countries because they would exclude and therefore discriminatory against the countries accounting for nearly $99 \%$ of the world trade. This discrimination works particularly to the disadvantage of India because of its high tariff barriers. China will be gainer in this process because of its much less tariffs compared to India.

When India gives duty free access to China, tariff revenue previously collected on the imports from China turns into exports revenues for the exporting firms of China, which is obviously very high because of high tariff regime in India. In this process Chinese firms will be much gainers compared to Indian exporters. This is because tariffs in China are low, Indian exporting firms have less to gain from the tariff free access in China. Conversely, when China gives duty free access to India, tariff revenue previously collected from the imports from India turns into export revenues for the export firms of India, which will be obviously very low because of lower tariffs in China. Since tariffs in India are very high, Chinese exporting firms have more to gain from the duty free access to India and Indian exporting firms will gain much less because of duty free access to China, which is having very low tariffs.

But, as a second best solution, increase in duty free imports from China might translate at least partial reduction in consumer prices, which will be substantially high, compared to reduction in prices to the Chinese consumers because of the existence of lower tariffs. Therefore, welfare gains of the Indian consumers will be higher than the welfare gains of the Chinese consumers. Nevertheless, as long as India continues to have higher tariffs than China, the danger of potential losses from the transfer of tariff revenue to the Chinese firms in the form of higher profits will remain. As Panagarya suggested that while thinking of India-China FTA, India should remain committed to non-discriminatory liberalization and make all out efforts to bring down its tariff down to the Chinese levels in 2-3 years time.

Though governments of both sides have not spelt out their plan as yet either for PTAs or FTA, it is more rational to think that FTA would be implemented in a phased manner rather than in one go. The first step to create a vibrant regional trading bloc between China and India is to move toward a PTA with reduced tariffs in a phased manner covering commonly agreed, selected, and manufactured services and agricultural products over a long time horizon and then to form FTAs. The ultimate goal should be a FTA with a free flow of goods, services, investment, labor, and capital. While moving towards this objective, one has to face so many complicated problems of other related arrangements. First, of this kind is to define 'rules of origin'. As Panagarya opines that given the already operational regional arrangement in this region, this is bound to result in a "spaghetti bowl" type of phenomenon where for a given product there could be several different tariff rates depending on what origin is assigned to it. Another related problem is the harmonization of standards between India and China and uniform certification procedures, which are vital to any kind of trade liberalization that lead to PTAs and FTA. Third problem one has to encounter is the identification of negative list of commodities of the 
respective countries and detailed plan to prune it in a phased manner followed by the preparation of comprehensive national schedules of items to be offered for concession. This may not be easy task when the tariff levels are asymmetrically distributed between these two countries.

After the removal of initial barriers against the FTA within next two years, India and China can initiate serious discussion on a comprehensive economic cooperation agreement. The agreement should be drawn in such a way so that gains and losses of both sides can be balanced. Indian manufacturing sector, such as toys, is already witnessing some losses without a FTA. India can gain in its service sector. Therefore, a comprehensive economic agreement involving goods and services would be appropriate.

China and India are emerging as major economic powers. For sustainable development of the world and Asian economies, China and India should be integrated into the Asian economy and simultaneously with the rest of the world. Open regionalism and trade cooperation between the world's two largest developing economies can foster outward-oriented development and intraregional trade based on comparative advantage and complementarities. 


\section{References}

Ashfaque H. Khan(1996), "Application of the Gravity Model”, in Study of the Emerging Trading Environment and Developing Asia, Conference on Country Studies, Country Report, Pakistan, Asian Development Bank, 1996,pp 1-9

Anderson, Kym \& Richard Blackhurst (eds.) (1979): Regional Integration and Global Trading System, New York, Harvester/Wheatsheaf.

Baldwin, Richard (1993): 'A Domino Theory of Regionalism', Centre for Economic Policy Research, Discussion Paper No. 857.

Batra, A. (2004), India's Global Trade Potential: The Gravity Model Approach, ICRIER Working Paper 151, December

Bhattacharya, Biswa N.(2006), "Understanding the Latest Wave and Future Shape of Regional Trade and Cooperation Agreements in Asia, CESlfo Working Paper 1856, May 2006, Centre for Economic Studies and the Ifo Institute for Economic Research, Munich, Germany, November.

Bhattacharyay Biswa N. and De Prabir (2005), Promotion of Trade and Investment between China and India: Toward a Regional Perspective, Asian Development Review, Vol. 22, Number 1, Manila.

Bhattacharya, S.K., \& R.K. Mehta (1997): 'SAPTA I, SAPTA II and SAFTA: Impact on India's Imports', South Asian Survey, 4(2), 259-275.

Bhatacharya, S.K., \& R.K. Mehta (2000), " The South Asian Preferential Trading Arrangements: Impact on Intra-Regional Trade," Asia Pacific Journal of Economics and Business, Vol. 4. No. 1, June 2000, Australia and USA, pp. 92-111.

Bhattacharya, S.K. and Nagesh Kumar (2001), "Extending Bangkok Agreement to the Developed Countries in the Asia Pacific Region: An Indian Perspective", Paper presented at the "Expert Group Meeting on the Revitalization of the Bangkok Agreement, UN-ESCAP, 29-30 October 2001, Bangkok

Bhattacharya, S.K. \& Bhattacharya, Biswa.N. (2006), Prospect and Challenges of Regional Trade, Investment and Financial Cooperation in Asia: Am Empirical Analysis of BIMSTEC Countries and Japan., CESIfo Working Paper 1725, May 2006, Centre for Economic Studies and the Ifo Institute for Economic Research, Munich, Germany

Bhattacharya, S.K. (2001), "Regional Trading Arrangements among SAARC Countries and India's Imports", South Asia Economic Journal, 2(2), July-December 2001

Bhattacharya, S.K. (2004), Does Bangladesh Benefit from Preferential Trade with India? A Gravity Analysis, Economic and Political Weekly, No. 48 pp.5152-62

Boillot, J.J. \& Labbouz, M. (2006), India - China Trade: Lessons Learned and Projections for 2015, Economic \& Political Weekly, June 30, pp. 2893-2901

CRISIL (2003), Indo-China Bilateral Trade, CRISIL Ecoview, CRISIL, New Delhi, July 
Deardorff, A V (1998): 'Determinants of Bilateral Trade: Does Gravity Work in a Neo-classical World?' in the Frankel J A (ed), Rationalization of the World Economy, NBER, University of Chicago Press, 7-32

Frankel, Jeffrey, Ernesto Stein and Shang-Jin Wei (1993): "Trading Blocs: The Natural, the Unnatural and the Super- Natural" paper presented at the Sixth Inter American Seminar in Economics (NBER) in Caracas, Venezuela

Frankel, Jeffrey and Shang-Jin Wei (1993): 'Trade Blocs and Currency Blocs', NBER Working Paper No. 4335

Frankel, J.A., and S. Wei (1995), "The New Regionalism and Asia: Impact and Options”, paper presented at the Conference, The Emerging Global Trading Environment and Developing Asia, held at the Asian Development Bank, Manila, May 29-31, 1995

Frankel, J A (1997): Regional Trading Blocs in the World Economic System, Institute of International Economics, Washington.

Garnaut, R.G. (1972), Australian Trade with Southeast Asia: A Study of Resistances to Bilateral Trade Flows, Ph.D. Dissertation, Australian National University

Govt. of India (2005), Report of the India-China Joint Study Group on Comprehensive Trade and Economic Cooperation", Ministry of External Affairs, New Delhi

Kalirajan, K. (1999), Stochastic Varying Coefficients Gravity Model: An Application in Trade Analysis, Journal of Applied Statistics, Vol. 26, No.2, pp. 185-193.

Kalirajan, K. (2000), "Indian Ocean Rim Association of Regional Cooperation (IOR-ARC): Impact on Australia's Trade," Journal of Economic Integration, 15, pp.533-547

Linnemann, H (1966): An Economic Study of International Trade Flows, North-Holland Publishing Company, Amsterdam.

Pigato, M et al (1997): South Asia's Integration into the World Economy, The World Bank, Washington

Poyhonen (1963): 'A Tentative Model or the Volume of Trade between Countries', Welsirtschaftliches Archive, 90(1), 93-99.

Rajapakse, Purnima \& Arunatilake, Nisha (1996), Would a Reduction in Trade Barriers Promote Intra-SAARC Trade? Institute of Policy Studies, Colombo, March 1996, pp. 1-29

Safadi, Raed and Alexander J Yeats (1993), 'The North American Free Trade Agreement: Its Effect on South Asia', World Bank: Policy Research Working Paper, pp. 1-32

Shand, R.T. and Kalirajan, K.P. (1997), 'Yamazawa's open economic association: An Indian Ocean Grouping for economic cooperation', The Developing Economics, 35: 3-25

Srinivasan, T N (1994): 'Regional Trading Arrangements and Beyond: Exploring Some Option for South-Asia: Theory, Empirics and Policy', Report No. IDP-142, South -Asia Region, World Bank, pp. 1-40 
Srinivasan,T.N. (1996), Regionalism and the World Trade Organization: Is Non-Discrimination Passe'? Economic Growth Centre, Yale University Centre Discussion Paper No. 767, December 1996, pp. 1-29

Srinivasan, T N \& Canonero, C (1993): 'Preferential Trade Arrangement: Estimating the Effects on South Asia Countries', Report, South-Asia Region, World Bank, September, pp. 1-58

Srinivasan, T.N., \& G. Canonero (1995), Preferential Trading Arrangements in South Asia: Theory, Empirics and Policy (unpublished), June 1995,

Tinbergen, J (1962): Shaping the World Economy: Suggestions for an International Economic Policy, New York.

Yamazawa, I. (1970) "Intensity Analysis of World Trade Flow", Hitotsubashi Journal of Economics, 10, 61-90

Wansbeek, T \& Kapteyn, A (1989): 'Estimating of the Error-components Model with Incomplete Panels', Journal of Econometrics, 41: 341-361.

i The ' new regionalism of nineties, unlike trading arrangements of sixties, has member countries with (a) vastly different levels of development, (b) different sizes of population, (c) different levels of domestic economies, and structure of production, and (d) varying degrees of openness, etc. For details, see WTO (1995), among others.

ii Pigato et al. (1997) have estimated the welfare consequences of a scenario when all tariffs between (a) India and (b) rest of the SMCs are removed. The welfare gains are trade creation benefits - trade diversion losses + terms of trade gains. The welfare results generate significant benefits for both India and the rest of the SMCs. However, it should be noted that the simulation is based on tariff rates of 1993-94 and 1997-98. There is free trade between India-Nepal and India-Bhutan under bilateral trading arrangements.

iii This portion is heavily drawn from the analysis of Mehta, R.K. and Bhattacharya, S. K., SAPTA to SAFTA: Impact on Intra-Regional Trade, Paper presented to the $35^{\text {th }}$ Annual Conference of the Indian Econometric Society, Jaipur, March 11-13, 1999. The author is very grateful to Rajesh Mehta for his contribution to the specification of the model.

iv Beata Kasia Smarzynska," Resurrecting the Gravity Model: In Search of the Centre of International Trade", mimeo, Yale University, p.4 


\title{
CESifo Working Paper Series
}

\author{
(for full list see www.cesifo-group.de)
}

1908 Liliana E. Pezzin, Robert A. Pollak and Barbara S. Schone, Efficiency in Family Bargaining: Living Arrangements and Caregiving Decisions of Adult Children and Disabled Elderly Parents, February 2007

1909 Christian Keuschnigg and Soren Bo Nielsen, Self-Selection and Advice in Venture Capital Finance, February 2007

1910 Rune Jansen Hagen and Gaute Torsvik, Irreversible Investments, Dynamic Inconsistency and Policy Convergence, February 2007

1911 Eric A. Hanushek and Ludger Woessmann, The Role of School Improvement in Economic Development, February 2007

1912 Bernard M. S. van Praag, Perspectives from the Happiness Literature and the Role of New Instruments for Policy Analysis, February 2007

1913 Volker Grossmann and Thomas M. Steger, Growth, Development, and Technological Change, February 2007

1914 Margarita Katsimi and Thomas Moutos, Human Capital and the Feldstein-Horioka Puzzle, February 2007

1915 Oliver Roehn, Theo S. Eicher and Thomas Strobel, The Ifo Industry Growth Accounting Database, February 2007

1916 Ian Babetskii, Aggregate Wage Flexibility in Selected New EU Member States, February 2007

1917 Burkhard Heer, Alfred Maussner and Paul D. McNelis, The Money-Age Distribution: Empirical Facts and Limited Monetary Models, February 2007

1918 Yin-Wong Cheung, Menzie D. Chinn and Eijii Fujii, The Overvaluation of Renminbi Undervaluation, February 2007

1919 Jim Malley, Apostolis Philippopoulos and Ulrich Woitek, To React or Not? Fiscal Policy, Volatility and Welfare in the EU-3, February 2007

1920 Mattias Polborn, Competing for Recognition through Public Good Provision, February 2007

1921 Lars P. Feld and Benno Torgler, Tax Morale after the Reunification of Germany: Results from a Quasi-Natural Experiment, February 2007

1922 Robert S. Chirinko and Huntley Schaller, Fundamentals, Misvaluation, and Investment: The Real Story, February 2007 
1923 Benno Torgler and Friedrich Schneider, Shadow Economy, Tax Morale, Governance and Institutional Quality: A Panel Analysis, February 2007

1924 Adrian Pagan and M. Hashem Pesaran, On Econometric Analysis of Structural Systems with Permanent and Transitory Shocks and Exogenous Variables, February 2007

1925 Hans-Werner Sinn, The Welfare State and the Forces of Globalization, February 2007

1926 Michael Smart, Raising Taxes through Equalization, February 2007

1927 Øystein Foros, Kåre P. Hagen and Hans Jarle Kind, Price-Dependent Profit Sharing as an Escape from the Bertrand Paradox, February 2007

1928 Balázs Égert, Kirsten Lommatzsch and Amina Lahrèche-Révil, Real Exchange Rates in Small Open OECD and Transition Economies: Comparing Apples with Oranges?, February 2007

1929 Aleksander Berentsen and Cyril Monnet, Monetary Policy in a Channel System, February 2007

1930 Wolfgang Ochel, The Free Movement of Inactive Citizens in the EU - A Challenge for the European Welfare State?, February 2007

1931 James K. Hammitt and Nicolas Treich, Statistical vs. Identified Lives in Benefit-Cost Analysis, February 2007

1932 Wilhelm Kohler, The Bazaar Effect, Unbundling of Comparative Advantage, and Migration, February 2007

1933 Karsten Staehr, Fiscal Policies and Business Cycles in an Enlarged Euro Area, February 2007

1934 Michele Bernasconi and Paola Profeta, Redistribution or Education? The Political Economy of the Social Race, March 2007

1935 Axel Dreher, Martin Gassebner and Lars-H. R. Siemers, Does Terror Threaten Human Rights? Evidence from Panel Data, March 2007

1936 Naércio Aquino Menezes Filho and Marc-Andreas Muendler, Labor Reallocation in Response to Trade Reform, March 2007

1937 Gebhard Flaig and Timo Wollmershaeuser, Does the Euro-zone Diverge? A Stress Indicator for Analyzing Trends and Cycles in Real GDP and Inflation, March 2007

1938 Michael Funke and Michael Paetz, Environmental Policy Under Model Uncertainty: A Robust Optimal Control Approach, March 2007

1939 Byeongchan Seong, Sung K. Ahn and Peter A. Zadrozny, Cointegration Analysis with Mixed-Frequency Data, March 2007 
1940 Monika Bütler and Michel André Maréchal, Framing Effects in Political Decision Making: Evidence from a Natural Voting Experiment, March 2007

1941 Giacomo Corneo and Olivier Jeanne, A Theory of Tolerance, March 2007

1942 Qing Hong and Michael Smart, In Praise of Tax Havens: International Tax Planning and Foreign Direct Investment, March 2007

1943 Yin-Wong Cheung, Dickson Tam and Matthew S. Yiu, Does the Chinese Interest Rate Follow the US Interest Rate?, March 2007

1944 Panu Poutvaara and Mikael Priks, Unemployment and Gang Crime: Could Prosperity Backfire?, March 2007

1945 Burkhard Heer, On the Modeling of the Income Distribution Business Cycle Dynamics, March 2007

1946 Christoph A. Schaltegger and Lars P. Feld, Are Fiscal Adjustments less Successful in Decentralized Governments?, March 2007

1947 Giovanni Facchini, Marcelo Olarreaga, Peri Silva and Gerald Willmann, Substitutability and Protectionism: Latin America's Trade Policy and Imports from China and India, March 2007

1948 C. Mirjam van Praag and Bernard M. S. van Praag, The Benefits of Being Economics Professor A (and not Z), March 2007

1949 Astrid Hopfensitz and Frans van Winden, Dynamic Choice, Independence and Emotions, March 2007

1950 Guglielmo Maria Caporale and Luis A. Gil-Alana, A Multivariate Long-Memory Model with Structural Breaks, March 2007

1951 Mattias Ganslandt and Keith E. Maskus, Wholesale Price Discrimination and Parallel Imports, March 2007

1952 Michela Redoano, Fiscal Interactions Among European Countries. Does the EU Matter?, March 2007

1953 Stefan C. Wolter, Rémy Hübschi and Matthias Müller, Push or Pull? An Empirical Analysis of the Demand for Individual Project Grants from the Swiss National Science Foundation, March 2007

1954 Scott Alan Carson, African-American and White Inequality in the American South: Evidence from the $19^{\text {th }}$ Century Missouri State Prison, March 2007

1955 Peter Egger, Marko Koethenbuerger and Michael Smart, Do Fiscal Transfers Alleviate Business Tax Competition? Evidence from Germany, March 2007

1956 Panu Poutvaara and Lars-H. R. Siemers, Smoking and Social Interaction, March 2007 
1957 Stephan Danninger and Fred Joutz, What Explains Germany's Rebounding Export Market Share?, March 2007

1958 Stefan Krasa and Mattias Polborn, Majority-efficiency and Competition-efficiency in a Binary Policy Model, March 2007

1959 Thiess Buettner and Georg Wamser, Intercompany Loans and Profit Shifting Evidence from Company-Level Data, March 2007

1960 Per Pettersson-Lidbom and Mikael Priks, Behavior under Social Pressure: Empty Italian Stadiums and Referee Bias, April 2007

1961 Balázs Égert and Carol S. Leonard, Dutch Disease Scare in Kazakhstan: Is it real?, April 2007

1962 Paul De Grauwe and Pablo Rovira Kaltwasser, Modeling Optimism and Pessimism in the Foreign Exchange Market, April 2007

1963 Volker Grossmann and Thomas M. Steger, Anti-Competitive Conduct, In-House R\&D, and Growth, April 2007

1964 Steven Brakman and Charles van Marrewijk, It’s a Big World After All, April 2007

1965 Mauro Ghinamo, Paolo M. Panteghini and Federico Revelli, FDI Determination and Corporate Tax Competition in a Volatile World, April 2007

1966 Inés Macho-Stadler and David Pérez-Castrillo, Optimal Monitoring to Implement Clean Technologies when Pollution is Random, April 2007

1967 Thomas Eichner and Ruediger Pethig, Efficient $\mathrm{CO}_{2}$ Emissions Control with National Emissions Taxes and International Emissions Trading, April 2007

1968 Michela Redoano, Does Centralization Affect the Number and Size of Lobbies?, April 2007

1969 Christian Gollier, Intergenerational Risk-Sharing and Risk-Taking of a Pension Fund, April 2007

1970 Swapan K. Bhattacharya and Biswa N. Bhattacharyay, Gains and Losses of India-China Trade Cooperation - a Gravity Model Impact Analysis, April 2007 